\title{
The Utilization Of Financial Information System To Support The Creation From Budget Costs Using e-Budgeting
}

\author{
Dewi Immaniar ${ }^{1}$, Mulyati $^{2}$, Ulfatul Jannah Putri Musliawati ${ }^{3}$ \\ ${ }^{1,2,3}$ Raharja University, Jl. Jendral Sudirman No.40 Modernland, Cikokol, Tangerang \\ e-mail: dewi.immaniar@raharia.info, mulyati@raharja.info, ulfatul@raharja.info
}

\begin{abstract}
In an era of modernization as this is now very much in the development of applications that make use of the computer program. One of them, namely the creation of the budget costs using ebudgeting application. What is the e-budgeting? E-Budgeting is a financial system that is stored online with the aim of transparency for each party. This system is applied as documentation for the preparation of the budget is usually in an area. Anyone can access data budget compiled by a local government so hopefully can prevent attempts of embezzlement of funds. The application of ebudgeting was chosen because it can bring cost transparency can be seen by anyone who is shown through the website. The results presented in this study is the use of proven e-budgeting nature of transparency compared with the way that still are conventional.
\end{abstract}

Keywords: The cost of the e-budget, budgeting, budget transparency.

\section{Introduction}

Financial information system is one of the things that are important in the production of financial statements [1]. Nowadays over rapid information technology came the electronic innovations using the utilization of technology. Discussed this time is the utilization of electronic-based financial information system or commonly called by E-budgeting [2]. E-budgeting is a financial system that is stored online with the aim of giving priority to transparency for each party [3].

E-budgeting has been regulated in law 23 years 2014 about local governance. This system is applied as documentation drafting budgets in a region. Anyone can access the data of the budget drawn up so hopefully can prevent the embezzlement of funds or fraud attempts of the local bureaucracy [4-6]. In addition, the preparation of the budget can be made more quickly, precisely and accurately as well as tackling corruption through criminal misappropriation of budget [7].

E-budgeting system now began to prove a number of advantages compared to conventional financial documentation application [8]. Among them, Prevent corruption corruption in some areas sometimes can be easily disguised with process manipulation of financial data. In particular, the Fund may diakali registration more easily because it is still using conventional systems such as the Excel application, that cannot be monitored directly online[9]. So, it goes without saying if any darkening or inflating the funds that suddenly happens in a local government financial data. By applying ebudgeting system, such efforts could be prevented because the data that has been input cannot be manipulated again and the data can be viewed publicly[10].

\section{Research Method}

The method of research is the description or plan of an activity that is arranged systematically scrutinized with the goal of keeping a research can be realized. On the research method using a SWOT analysis. 
According to Blocher (2007) cited from the journal Fortunately Rahardja (2019), stating a SWOT analysis is a systematic step that aims to identify the factors that determine your success, including: internal strengths and weaknesses and externally, include: opportunities and threats [11].

While according to Prompt (2014) SWOT analysis is an important planning strategy to compare the internal factors, namely: the strengths and weaknesses and external opportunities and threats, that is.

Formulation of a SWOT analysis based on the fact that exists between internal facts with external situations. Conformity of good will bear a positive impact from the company's strengths and minimize the weaknesses as well as opportunities and threats will happen.

Table 1. Analysis SWOT

\begin{tabular}{|c|c|c|}
\hline & Strength & Weakness \\
\hline External & $\begin{array}{l}\text { To prevent } \\
\text { manipulation of the } \\
\text { budget funds. } \\
\text { It can be accessed } \\
\text { anytime anywhere } \\
\text { publicly. }\end{array}$ & $\begin{array}{l}\text { Device can be error. } \\
\text { Always need network of } \\
\text { the internet. }\end{array}$ \\
\hline Opportunity & Strategy SO & Strategy WO \\
\hline $\begin{array}{l}\text { Related parties may play an } \\
\text { active role in guarding } \\
\text { against data that has been } \\
\text { saved. }\end{array}$ & $\begin{array}{l}\text { The leader can control } \\
\text { and evaluate directly } \\
\text { Provide a faster } \\
\text { process in the } \\
\text { preparation of the } \\
\text { budget }\end{array}$ & $\begin{array}{l}\text { Prevent corrupt } \\
\text { practices }\end{array}$ \\
\hline Threat & Strategy ST & Strategy WT \\
\hline $\begin{array}{l}\text { Vulnerable burglarized by } \\
\text { hackers. } \\
\text { Exposed to the influence of } \\
\text { online viruses that can } \\
\text { corrupt data }\end{array}$ & $\begin{array}{l}\text { Still be put forward in } \\
\text { terms of the } \\
\text { optimization of } \\
\text { technical and } \\
\text { management } \\
\text { capabilities right from } \\
\text { the responsible HR }\end{array}$ & $\begin{array}{l}\text { Ignoring this aspect of } \\
\text { the analysis of benefits. } \\
\text { Only include one-year } \\
\text { budgets so that less can } \\
\text { explain expenses as a } \\
\text { result of more than one } \\
\text { financial year. }\end{array}$ \\
\hline
\end{tabular}

According table 1. There is a SWOT analysis that identified internal and external factors which include Strength, Weakness, Opportunity and Threat. Then it can be inferred by researchers deduce the strategy SO based on a comparison between the strength and opportunity is the leader can control and evaluate directly and provide a faster process in the preparation of the budget . ST strategies applied in the comparison between the strength and threads is still be put forward in terms of the optimization of technical and management capabilities right from the responsible HR . WO strategies can be applied on the basis of a comparison between the weakness and opportunity is Prevent corrupt practices. WT strategies Weakness and Threat, the possibility of negative happens 
is Ignoring this aspect of the analysis of benefits and only include one-year budgets so that less can explain expenses as a result of more than one financial year.

\section{Results and Analysis}

\section{A. Interface Main Page}

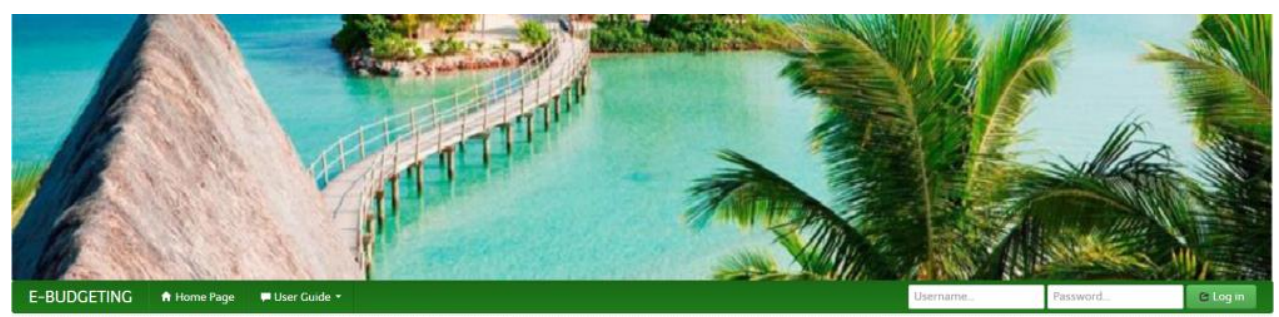

Selamat Datang di Sistem Informasi Anggaran Keuangan e-budgeting adalah sebuah sistem pembuatan anggaran di lingkungan kantor.

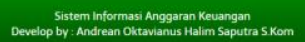

Figure 1. Interface Main Page

Based on figure 1, the page shows a brief explanation regarding the Financial Budget information system. On this page there is a guide that contains about anything that can be done by the user. On the System Information is 1, i.e. the user admin. Then there is a login form. A user who can log on are those which have been registered in the database. To register a new user, it can be done by Admins.

\section{B. Interface Admin Access}

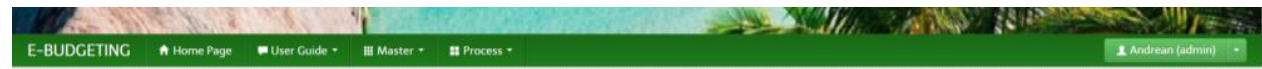

Selamat Datang di Sistem Informasi Anggaran Keuangan

\section{Figure 2. Interface Login Admin}

Based on figure 2, after login as admin, look no different from the login page, there are only 2 additional menu, i.e. the Master and the Process and there is a menu that contains settings for the admin user. The specified setting is to change personal information, change your password, add new admin and logout.

\section{Interface Master Menu}

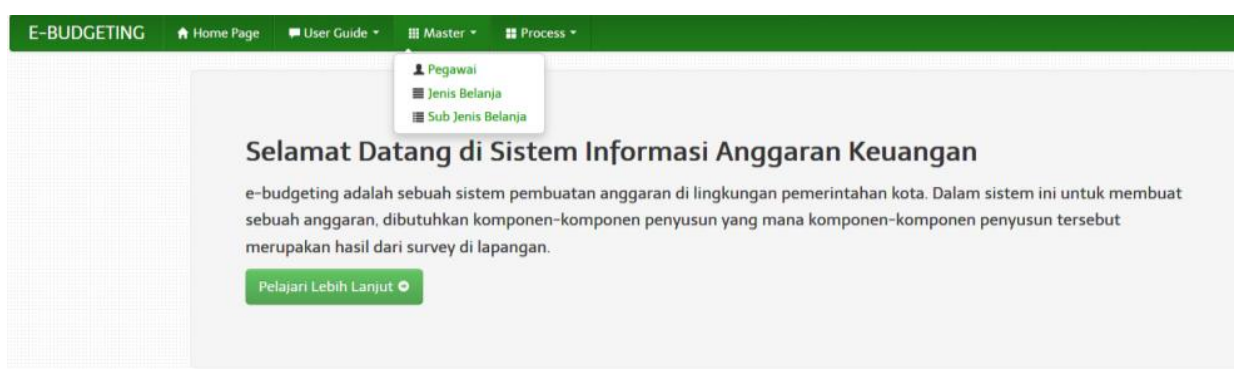

Figure 3. Master Menu 
Then, when the master menu is clicked, 3 sub menu will appear, i.e. employees, types of shopping, and the Sub type of shopping. Each sub menu contains things that will be used at the time of the making of the budget report.

\section{Interface Employees Submenu}

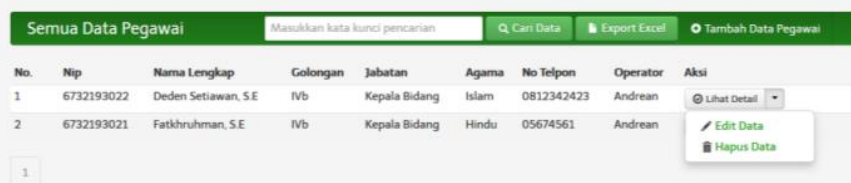

Figure 4. Employees Submenu

On the submenu will display data the employees, employees working in companies or offices. Employee data that will be displayed is Nip, full name, category, title, religion, No. The phone and the Operator. Then on the right side there is a choice of action. The choice of this action contains two options, i.e. Edit data to modify data related employees and delete Data to remove any employee related. In addition, on this page, the admin can search employees based on certain criteria, Export Excel function to download the employee data into the Excel file and Add Employee Data to add a new employee data.

If the option to delete the Data on the Action is clicked, then a message will appear asking if the correct admin will delete the data. This is to prevent in case of wrong click, then no data will be instantly erased.

\section{E. Interface Shopping Submenu}

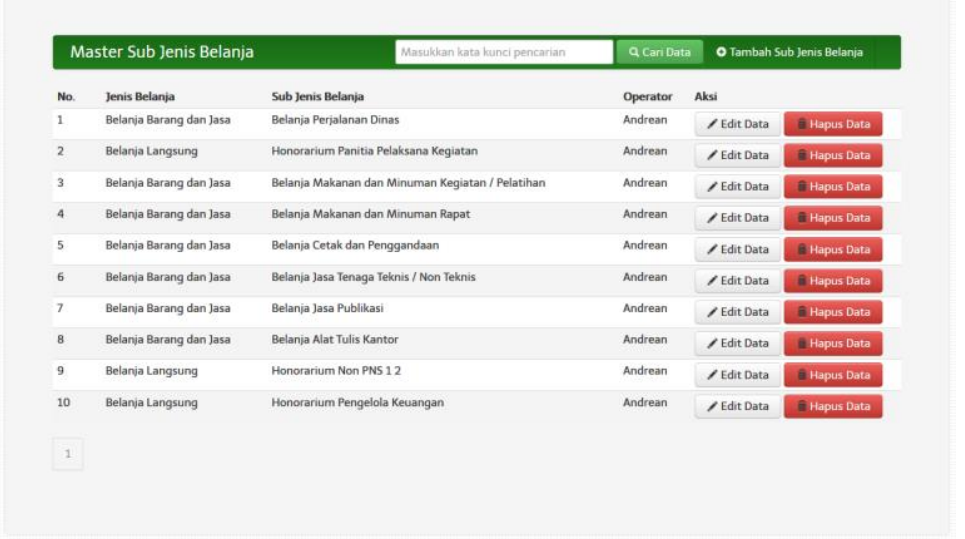

Figure 5. Shopping Submenu

On the submenu, there is Shopping kind of list type of shopping that will be budgeted. The data shown is a shopping list Description and who the user input data. We can also add new shopping list in the Add option type of shopping. There is also a form of Search when looking for data based on certain criteria. Then on the right side of each list of data types of shopping, there is a form of action which contains the Edit Data and delete Data. True to its name, Edit the Data used to perform the edit data types of shopping and delete Data to remove any shopping list.

Then on the submenu, there is Shopping kind of Sub list sub type of shopping. Data shown is a type of shopping, Sub types of shopping and who the operators are doing data input. Above the table list Sub types of Shopping there is a search form to search data Sub types of Shopping based on your keywords and Add button Sub types of shopping for adding data Sub types of new Spending. 
On the right side of each list Sub types of Shopping there is 2 options of action, i.e. Edit Data to do edit on the selected data and delete to delete the selected data.

In addition to the Master, on the admin login page there is a menu called Process. On the menu is this budget Process started based on the data in the Master menu. This menu contains 3 submenus, Data General, the Budget, and the final report.

\section{F. Interface General Submenu}

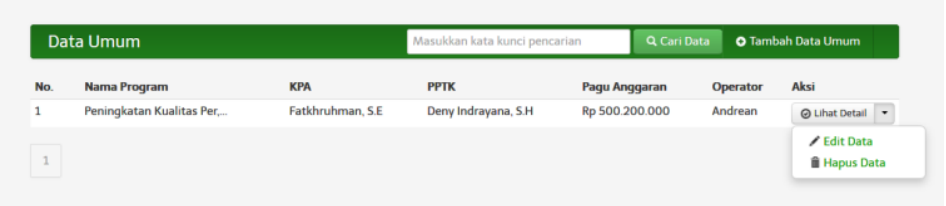

Figure 6. General Submenu

In General Submenu budget there are what is already created. The data displayed in the list in the form of the name of the program to be budgeted, KPA (power user budget), PPTK (Implementing Technical Activities Officer), Launched the budget (the amount of rupiah budget given), and the user who made the budget. Then, on the right side of the table there is a Button View Details to view the details of the budget report and when the arrow is clicked, then the button will appear 2 other options, i.e. Edit Data to do edit the selected data and delete Data that serves to delete the selected data. On this page the user can also search for data with specific keywords and adding new budget data.
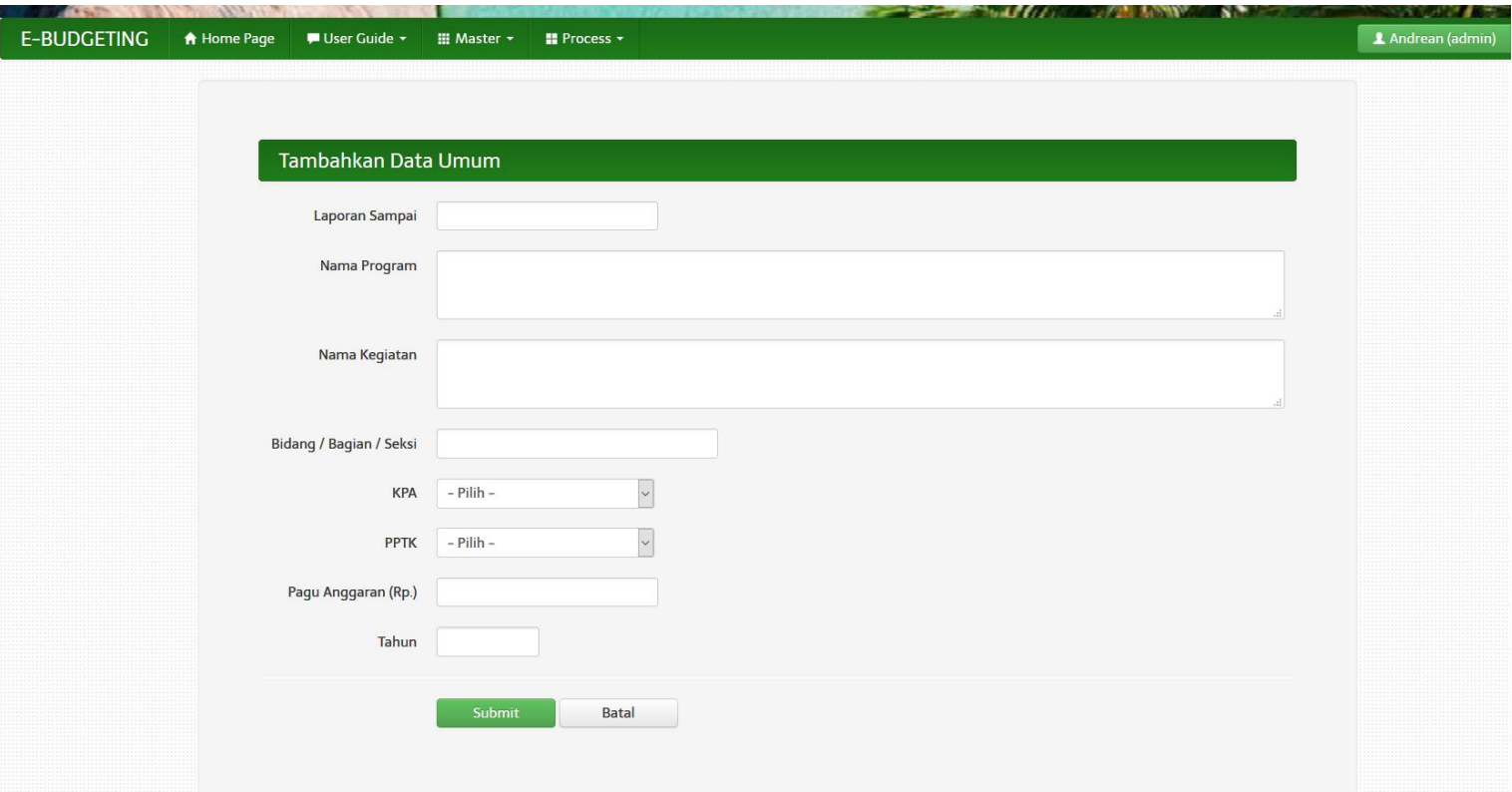

Figure 7. Interface General Data

When will add new data, it will pop up a blank form to be filled in by the user. In this form there is a form to Report i.e. the deadline reports the budget will be used, the name of the Program i.e. the name of the budget report to be made, the name of the activity is an activity that will be made to the budget report, the field/Section i.e. the areas where that makes this budget. On the form, the user PPTK KPA and don't need to do the input dropdown list is provided for employees who are registered in the database, so the user need not fear typo. Then Launched a budget is the amount of dollars budgeted for related programs as well as the Year the year the budget is made. 


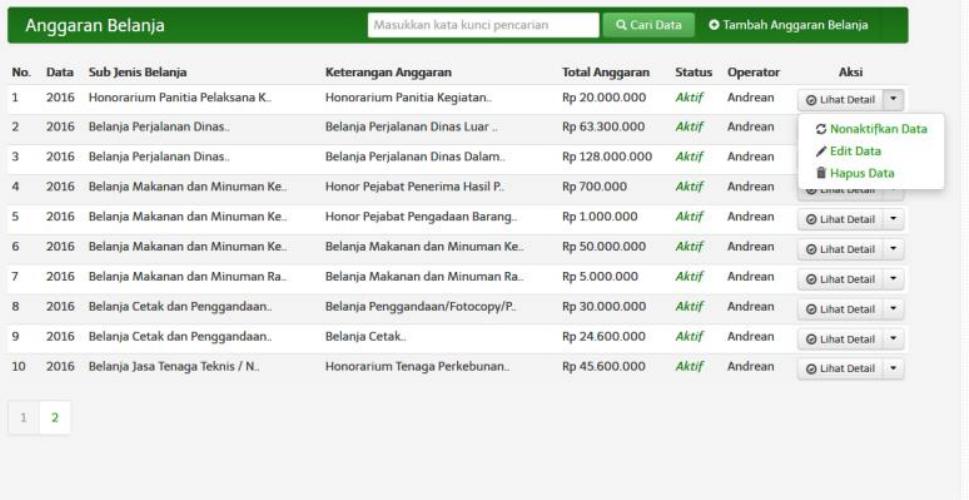

Figure 8. Budget Submenu

In a Budget submenu, there is a lists all the shopping that exist in the program budget data. the data shown in the table is the year, Subtypes of Shopping, a description of the budget, the Total budget of each list, Status, and the user who did the input. The user can Edit, delete and enable or disable the shopping button that's located on the right side of each list of data budget. Users can also search for data based on keywords and adding new budget data.

When going to add or edit data on a budget, then it will appear the following form:

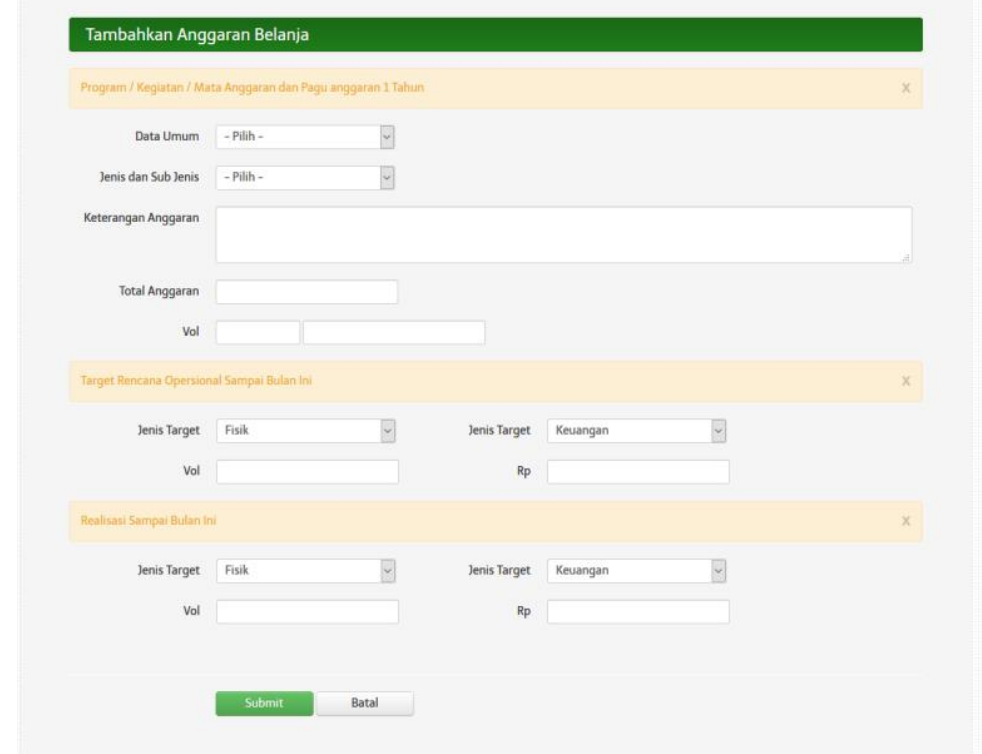

Figure 9. Input Data

General Data on the form as well as the type and Sub type, users just need to select the data from the dropdown list that contains the data that you already inputted by the user before. Then here user can also input target of goods or services that will be budgeted and realisation until this month.

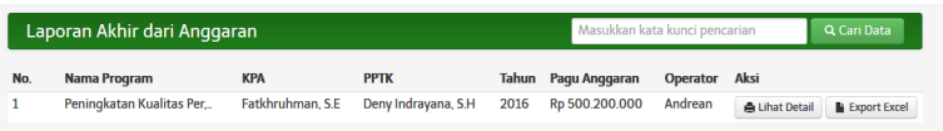

Figure 10. Final Report

Then, the third sub menu i.e. the final report. There is a table of the final report of the budget. This table displays the data on the Program name, KPA, PPTK, years, Launched the budget and the user who made the report. On this page, the user can not do edit or delete, because on this page only 
shows the final report from the budget-a budget that was made earlier. But the user can still see the details and download the report. The report will be downloaded in the form of Excel files. And when the action View Details clicked, then the user will be directed to a new page to do a print of the budget report details.

\section{Conclusion}

Method E-Budgeting is one example of innovation industry 4.0 which is frequently used in the world of Government. This method is a new method that will get rid of the old functions such as excel. With this e-budgeting, financial information system activities provide ease in a variety of ways, including the following:

1. Simplify admin in making the report or details of financial costs so it can be evaluated as soon as possible by the leadership directly.

2. It can be accessed anytime anywhere publicly, dengan syarat harus terkoneksi dengan jaringan internet.

3. To prevent manipulation of the budget funds so that is not the case of embezzlement of money.

\section{References}

[1] Sutabri. 2012. Konsep Dasar Informasi. Yogyakarta: Andi

[2] Cid, G. P., \& Gil-García, J. R. (2004). ENACTING E-BUDGETING IN MEXICO (1). Public Finance \& Management, 4(2).

[3] Rachmat, B., \& Andika, A. (2016). Efektivitas Pelaksanaan Sistem e-Budgeting di Kelurahan Kebonkosong Daerah Khusus Ibu Kota Jakarta. Jurnal Manajemen Pemerintahan Transformasi Pemerintahan, 8(2), 79-93.

[4] Suhendra, A. (2017). Kesiapan Pemerintah Daerah dalam Mewujudkan Kota Cerdas di Bandung dan Surabaya. Matra Pembaruan: Jurnal Inovasi Kebijakan, 1(1), 1-9.

[5] Hornyak, S. (1998). Budgeting made easy. Strategic Finance, 80(4), 18.

[6] Suhendra, A. (2017). Kesiapan Pemerintah Daerah dalam Mewujudkan Kota Cerdas di Bandung dan Surabaya. Matra Pembaruan: Jurnal Inovasi Kebijakan, 1(1), 1-9.

[7] Hidayat, R. (2014, August). e-Procurement PracticesinFourAreasinEast Java, Indonesia: Accountability, Efficiency and Barriers. In 2014 International Conference on Public Management. Atlantis Press.

[8] Tiara K, Nurhaeni T, Faradisa Y. PENERAPAN GO+ BERBASIS WEB UNTUK MENINGKATKAN MUTU PELAYANAN LEMBAGA KEUANGAN MAHASISIWA. Technomedia Journal. 2017 Mar 1;1(2):90-105.

[9] ROSALINA, V. W. (2016). IMPLEMENTASI E-BUDGETING TERHADAP KINERJA INSTANSI PEMERINTAH KOTA SURABAYA DENGAN PENGENDALIAN INTERNAL SEBAGAI VARIABEL MODERASI (Doctoral dissertation, UNIVERSITAS AIRLANGGA)

[10] Gunawan, D. R. (2016). Penerapan Sistem E-Budgeting Terhadap Transparansi Dan Akuntabilitas Keuangan Publik (Studi Pada Pemerintah Kota Surabaya). AKRUAL: Jurnal Akuntansi, 8(1), 72-102.

[11] Rahardja, U., Lutfiani, N., Lestari, A. D., \& Manurung, E. B. P. (2019). Inovasi Perguruan Tinggi Raharja Dalam Era Disruptif Menggunakan Metodologi iLearning. Jurnal IImiah Teknologi Informasi Asia, 13(1), 23-34. 